Izmaylov $\mathbf{Y}$.

\title{
SUBSTANTIATION OF THE PROCEDURE FOR THE REFLECTION OF GOODWILL IN THE ACCOUNTING SYSTEM OF NATIONAL ENTERPRISES
}

Проведено аналіз існуючих підходів до загальноекономічного та регламентованого в бухгалтерському обліку трактування поняття гудвілу. Розглянуто передумови впровадження в облікову практику та поступового розширення використання в національній системі обліку гудвілу підприємства. Запропоновано модифіковану класифікащію гудвілу за ознаками приналежності, якісної оцінки та надходження бізнес об’єктів. Уточнено порядок обліку позитивного гудвілу та доведено доцільність повернення до відображення в національній системі обліку негативного гудвілу (бедвілу).

Ключові слова: гудвіл, бухгалтерсвкий облік, класифікація гудвілу, об'єднання підприємств, негативний гудвіл (бедвіл).

\section{Introduction}

Formation of a positive reputation of the enterprise is a necessary condition for achieving a long and sustainable development of the enterprise on investment-innovative principles. Goodwill becomes an important means of strengthening the competitive position of the enterprise, as it provides additional advantages in the sales markets, labor, capital, resources, etc. It affects the value of the company and determines its opportunities in attracting funds, searching for strategic investors and partners, building relationships with the authorities and shaping the demand and loyalty of consumers. A positive reputation is an especially important component of success, which helps protect the company, increase the value of shares and the market value of the company's assets, therefore, affects the effectiveness of its activities. The formation and use of accounting and analytical information about business reputation in the current conditions of globalization and informatization of economic life is an important factor in the country's investment and innovation development.

In the global economic environment, «goodwill» category is most often identified with business reputation, image, popularity, brand, customer base, innovative technologies, etc. Consideration of this concept attracts the attention of many scientists. Therefore, «goodwill» has become part of important interdisciplinary terms.

In accounting, goodwill in value terms is the amount that an enterprise buyer is willing to pay more than the carrying amount of its assets. When accounting for goodwill, interested parties receive information about the market and book value of the enterprise. At the same time, goodwill is constantly changing depending on positive and negative information about the activities of the enterprise. Therefore, to increase the investment attractiveness and presentation of information about the company to interested users, it is very important to develop research aimed at full and reliable reflection of goodwill in the accounting system.

\section{The object of research and its technological audit}

The object of research is the criteria influencing the goodwill formation. With the goal of effectively generating information on goodwill of companies, the International Reputation Institute (IRI) [1] managed to form six critical components of the reputation of any business, the quality of work with which directly affects the company's success in the market. According to this approach, the reputation of any company consists of the following six components that are taken into account by the target groups when forming a firm opinion on the company: emotional attractiveness, product quality, relations with partners, top management reputation, social responsibility, and financial indicators.

The US company Range Resources Corporation (RRC) [2] uses 9 complex criteria with weighting factors to assess the factors influencing the formation of the company's goodwill: competitiveness; professional ethics; leadership qualities of top managers; financial stability; social responsibility; manufacturing process; staff stability; marketing efficiency; charity.

Measures to reform and implement goodwill accounting at Ukrainian enterprises are not yet systematized. Therefore, some of them are doomed to failure because of the inability to adapt traditional accounting and reporting systems to the knowledge economy. The current goodwill accounting methodology in Ukraine has certain weaknesses, which do not allow to properly reflect this account in the accounting and reporting of enterprises, which is experiencing a consistent content. With this in mind, the methodological ambiguity and discussion of many accounting issues of goodwill, the need to clarify the accounting methodology and report on it determine the relevance of consideration of this issue.

\section{The aim and objectives of research}

The aim of research is to analyze the information reflection on goodwill of enterprises in the accounting system of Ukraine and reporting in the current economic situation. 
To achieve this aim, the following objectives are defined:

1. To analyze existing approaches to the general economic and accounting regulation of the interpretation of goodwill concept and its components.

2. To determine the relevance and necessity for presenting information on business reputation, image, prestige and goodwill in the accounting and analytical system of the enterprise.

3. To conduct a comprehensive analysis of the parts and contact groups that affect the formation of information on goodwill in the accounting and reporting system.

4. To analyze national and foreign approaches to the appropriateness of reflecting negative goodwill in accounting and reporting.

5. To give recommendations on accounting for positive and negative goodwill.

\section{Research of existing solutions of the problem}

Methodological approaches to the assessment, accounting and reporting of goodwill of an enterprise are widely discussed by many domestic and foreign researchers. Aspects of accounting for goodwill and its impact on the results of managing enterprises are reflected in the works of scientists around the world. The study [3] presents a meta-analytical review of factors that have a deterrent effect on corporate reputation. This study is useful for Ukrainian enterprises because, having determined the list of negative factors, it is possible to limit their influence on the reputation of the enterprise than to stimulate development processes.

Measurement of business reputation level is presented in [4] on the example of the study of small and mediumsized companies in New Zealand. Although this experience is very interesting, Ukrainian enterprises have many industry specificities and differences in business from developed countries. Therefore, the proposed procedure can be used by adapting to the conditions of Ukrainian enterprises.

The effect of goodwill on the credit rating of enterprises is investigated in [5]. It is logical that the larger the amount of goodwill will be reflected in the reporting of the enterprise, the more it becomes attractive to investors and counterparties, and especially the possibility of attracting credit resources increases. The goodwill asymmetry in time is analyzed in [6].

In [7], the order of creation of benefits and decrease in expenses for intellectual capital is represented on an example of small family firm. In [8], the state and prospects of information presentation on goodwill of national enterprises are analyzed. The authors carry out research for the purposes of corporate enterprises, but accounting for goodwill, attention is almost not paid. In [9], goodwill is investigated as a component of the intellectual capital of a firm. The authors offer the possibility of measuring the intellectual capital of a firm with the help of performance indicators as opposed to classical balance sheets. The proposal is interesting, but in the legislative field of Ukraine the main principle of accounting is a single monetary measure.

In work [10], recommendations on the account of goodwill on an example of firms of Australia are given. In particular, a comparative analysis of the impairment of the actual amount of goodwill with the accrued minimum depreciation is carried out. The procedure for reflection of impairment of goodwill and its depreciation for Ukrainian enterprises can be applied, but with the carrying out of studies for reflection of these transactions in the accounts of accounting.

Analysis of the financial statements of national companies shows almost complete absence of information about goodwill. This is due to inadequate research and unsystematicity associated with the novelty of the category and the lack of experience in accounting and reporting in order to increase the investment attractiveness of enterprises that require the development of research in this direction.

\section{Methods of research}

In the process of research, the following methods were used: dialectical, generalization, comparison, system analysis, observation of economic activity, balance sheet, etc.

\section{Research results}

Traditional system of accounting and financial reporting is aimed at reflecting indicators in retrospect. Therefore, it needs to adapt to meeting the needs of the enterprise in the formation of reasonable, reliable, timely and complete information about the goodwill of the enterprise that could affect the company's development prospects.

Due to the lack of explored opportunities and a systematic way of reflecting information on goodwill of the enterprises in the national accounting and reporting system, there should be a lack of official statistics on goodwill at the national level.

The purpose of collecting, accumulating, interpreting and presenting information on business reputation, image, prestige and goodwill in the accounting and analytical system of an enterprise is the solution of the following tasks:

- collection and interpretation of information on the

economic activities of the enterprise and competitors;

- obtaining competitive advantages;

- search for reserves with the definition of strong and weak places of the enterprise;

- developing the potential and increasing the value

of the enterprise;

- forecasting of the company's product prospects in the markets.

In the practice of business relations and their legal support, economic categories such as «goodwill», «business reputation», «image», «prestige», «good name» are clearly distinguished.

Based on the analysis of scientific literature [7], one can agree that economic categories «reputation», «image» and «goodwill» are close in meaning, but at the same time, they have significant differences.

Moreover, after analyzing these terms from a legal point of view, the author fully shares the results of the study [11] in which it is proved that each of these categories is independent, has a different legal nature and different directions of its intrasystem signs. The content of these legal concepts is the result of the realization of certain rights, which influences, among other things, on business reputation.

A thorough study of the scientists' findings regarding the interpretation of the economic categories in question revealed the lack of a common view on whether there are 
technologies of reputation formation, or only the image is subject to targeted design. The dominant among specialists $[8,11]$ can be considered the opinion that the positive or negative reputation of the enterprise consists of the passage of time, and the image must be constantly and actively formed. However, reputation can be formed by thought out consistent actions. Then in everyday life it allows the enterprise to work productively, proceeding from crisis and difficult situations with the least losses.

The management of the enterprise must promptly prevent the occurrence of major events that reduce the achieved level of reputation, image and goodwill of the enterprise. To such circumstances, which cause the appearance of negative perception of the company in business circles, include:

1) low level of social responsibility;

2) lack of investment in the development and implementation of modern technology and technology;

3) bankruptcy;

4) corporate conflict;

5) technogenic catastrophes;

6) change of majority shareholders in case the new owner has a reputation level lower than the previous one, etc.

At the present stage of development of theory and methodology of accounting, it is recommended to consider «goodwill» as an accounting element with inclusion of such components as «business reputation», «image», «prestige», «good face» in it.

General economic definition of the essence of «goodwill» term is several centuries old. At first this concept characterized the business reputation of an individual. The first official mention of goodwill was made in 1571, and a court hearing on its assessment of the buyer's claim to the business entity occurred in 1620. In the XIX century «goodwill» term went from the legal to the accounting practice, because it was recognized as a property right. Therefore, there was a need for its evaluation and accounting.

In [8] it is noted that the object of reflection in accounting can be only «acquired goodwill», which arises from the sale of an enterprise, that is, the goodwill for which money was paid.

Over time, the views on goodwill as an accounting object were somewhat transformed, gaining a great deal of concretization in the presentation of accounting information. In particular, in [12], goodwill is defined as:

1) the difference between the book value and the market value of assets;

2) the intellectual assets of an enterprise that can generate value, have not found their accounting reflection (that is, all intellectual assets, except for objects of intellectual property rights), as well as the cost of synergistic effects that arise as a result of their interaction.

In [13], goodwill is identified with «business reputation» and «company brand». The value of goodwill is defined as the excess of the acquisition price of the company at the value of net assets recorded in its balance sheet or as the excess of the acquisition share over the fair value of the identifiable assets and liabilities at the acquisition date.

In accordance with International Financial Reporting Standard (IFRS) 3 «Business Combinations», goodwill arising on business combinations is the amount paid by the buyer that exceeds the market value of the acquisition in anticipation of future economic benefits. Goodwill is defined as the excess of acquisition cost over the acquired share in the fair value of the identifiable acquired assets, is inseparable from the acquired enterprise. The actual value of goodwill is acquisition cost less the difference in the fair value of the identifiable assets, liabilities and contingent liabilities [14].

American accounting standards US GAAP, FAS 142, «Goodwill and Other Intangible Assets» treats goodwill as the excess of price of acquired company over the cost of its identifiable assets less liabilities [15].

According to Ukrainian regulations of accounting, namely Regulations (standard) of accounting (R(S)A) 19, «Business Combinations», goodwill is determined as the excess of acquisition cost over the acquirer's interest in the fair value of the identifiable assets and liabilities at the date of acquisition [16].

According to the Tax Code of Ukraine, goodwill (value of business reputation) is an intangible asset, the value of which is determined as the difference between the market price and the book value of the assets of the enterprise as an integral property complex, arises from the use of the best managerial qualities, the dominant position in the market of goods, services of new technologies [17].

Based on the analysis, it is recommended to consider goodwill for accounting purposes, as a sum of intangible intellectual assets and synergetic effects, materialized when the company is combined or acquired in the form of the difference between its market price and the book value of assets.

There is a dependence that due to the increase in goodwill cost, the cost of the innovative product of the enterprise increases and vice versa. Goodwill arises only in the case of the acquisition and combination of enterprises, and internally generated goodwill is not reflected in the accounting records at all.

Goodwill is an intangible asset that creates significant value for the company. At the same time, it should be noted that the accounting valuation of the goodwill of the enterprise does not provide users with information about the intellectual capital of the company due to the fact that:

1) amount of goodwill is determined only at the time of the sale or business combination, and the elements of intellectual capital are in constant motion;

2) profitability, prospects for development and market value of the enterprise largely form elements of human capital (skills and knowledge of workers), communications, brand, business reputation, etc.;

3) amount of goodwill does not give an idea of the individual structural elements, types and value of intellectual capital;

4) amount of goodwill is affected by the premium that the buyer pays for gaining control over the business and the speculative component of a particular contract of sale.

Between economic and accounting approaches to the interpretation of goodwill, there are several significant differences. According to accounting standards, goodwill can only be assessed when enterprises are acquired or combined. The economic approach allows calculating goodwill (with its components) at any time. Economic goodwill is constantly declining, and accounting goodwill remains constant.

For the purposes of accounting and reporting, it is proposed to classify goodwill by characteristics, shown in Fig. 1.

It is recommended to take into account the influence of the following contact groups on goodwill formation, each of which has its own priorities (Fig. 2). 


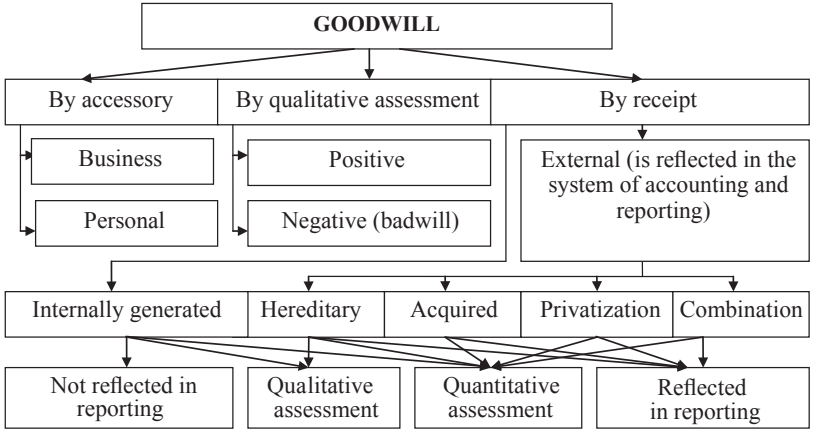

Fig. 1. Modified goodwill classification based on accessories, qualitative assessment and receipt of business objects for accounting purposes. Note: compiled by the author

\begin{tabular}{|c|l|l|}
\hline CONTACT GROUPS & \multicolumn{1}{|c|}{ PRIORITY GOALS } \\
\hline Shareholders & $\longrightarrow$ & $\begin{array}{l}\text { Profitability, financial stability, openness of information } \\
\text { and transparent dividend policy }\end{array}$ \\
\hline Staff & $\longrightarrow \begin{array}{l}\text { Dynamics of the enterprise development, ensuring a high } \\
\text { return on investment, profitability, financial stability }\end{array}$ \\
\hline Investors & $\longrightarrow \begin{array}{l}\text { Completeness of payment of taxes, social responsibility, } \\
\text { observance of the current legislation }\end{array}$ \\
\hline State & $\longrightarrow \begin{array}{l}\text { Compliance with business ethics and commitments, } \\
\text { solvency of the enterprise }\end{array}$ \\
\hline $\begin{array}{c}\text { Consumers and } \\
\text { competitors }\end{array}$ & $\begin{array}{l}\text { Quality of goods/services, pricing policy of the } \\
\text { enterprise }\end{array}$ \\
\hline
\end{tabular}

Fig. 2. Recommended consideration of the priority objectives of contact groups that affect the formation of goodwill. Note: compiled by the author

According to Ukrainian and International Financial Reporting Standards, the buyer must recognize the goodwill resulting from the combination of the business as an asset and perform its valuation at actual cost at the date of acquisition of the economic entity using formula (1):

$$
G=C A M-I N A F V,
$$

where $G$ - goodwill; $C A M$ - the cost of the acquisition or combination; INAFV - identifiable net assets at fair value.

If a share (less than $100 \%$ ) is purchased in net assets, the cost of goodwill is determined by the formula (2):

$$
G=C A M-S \% \times I N A F V,
$$

where $S \%$ - the company's share in the net assets of the acquired business.

In the process of accounting for goodwill, it is necessary to emphasize what happens to the enterprise that is trying to acquire: it is either liquidated or becomes a subsidiary.

If the enterprise is liquidated, the buyer, starting from the acquisition date, must reflect in the balance sheet the assets and liabilities of the acquired enterprise together with the goodwill arising from the acquisition. Subsequently, the book value of goodwill and its amortization is recorded in the accounts of the enterprise-buyer. If the acquired enterprise is not liquidated but continues to operate under the control of the buyer (the parent enterprise), the goodwill is shown not in a separate balance sheet of the buyer, but in the group's consolidated balance sheet under goodwill with consolidation, which is depreciated over the period of its expected profitability. Records on the calculation of goodwill amortization are not reflected in the accounting of the parent enterprise, but are corrective and affect the indicators of the consolidated financial statements only.

It is advisable to distinguish two main approaches in the world practice to goodwill reflection as an asset in the accounting system.

The first approach is goodwill capitalization - its reflection in the balance sheet as an intangible asset of long-term use with amortization or without depreciation. According to paragraph 55 of IFRS 3 « Business Combinations», goodwill acquired as a result of business combination is not subject to amortization. However, the buyer should check the goodwill for impairment annually or more frequently if events or changes in circumstances indicate the possibility of impairment in accordance with IFRS 36 «Impairment of Assets». So, if depreciation is not accrued, then goodwill is accounted as a permanent not depreciated asset similarly accounting for land plots. In this case, in the event of a decrease in the fair value, goodwill must be discounted.

According to the second approach, goodwill is not recognized in the asset in the accounting, and the cost of its acquisition is written off due to the reduction of the owners' capital.

However, it should be noted that here it is about (external) accounting goodwill. This goodwill appears as a result of acquisition, combination or other way of getting an enterprise.

According to R (S) A 19 «Business Combinations» [16], the initial (balance) cost of goodwill in accounting is amortized, but not more than 20 years. Goodwill is accounted as part of non-current assets on Account 19 «Goodwill» of Class 1 «Non-current assets». In particular, it provides for two sub-accounts: 191 «Goodwill on acquisition», and $193 \ll$ Goodwill during privatization (corporatization)». Goodwill in the balance sheet is recorded at the residual value in the line «Goodwill» with a positive or negative value.

Let's consider an example: The enterprise has 10.000 shares in the authorized capital of the subsidiary. The nominal value of one share is $800 \mathrm{UAH}$. The acquisition cost of each share is $880 \mathrm{UAH}$. So, in the balance sheet of the parent enterprise, financial investments are reflected in the actual value of the shares, that is, the amount of investments is $8800000 \mathrm{UAH}$. In the consolidated balance sheet, the positive difference between the actual and nominal value of shares (800 thousand UAH) should be reflected in intangible assets as goodwill upon consolidation: Debit 193 «Goodwill on consolidation» Credit 685 «Settlements with other creditors».

Enterprise-buyer at the accounting implementation of the operation for acquisition of the enterprise in the case of reflection of the positive goodwill has an accounting transaction: Debit 191 «Goodwill on the acquisition» Credit 685 «Settlements with other creditors». The loss from impairment is reflected as follows: Debit $977 \ll$ Other expenses of ordinary activities» Credit 191 «Goodwill on acquisition». 
The useful time of goodwill is determined taking into account the projected life of the enterprise, regulations or contracts affecting the useful life, changes in demand for products (works, services) of the enterprise, etc. If goodwill at the end of the year does not correspond to the asset characteristics, it is written off with the inclusion of the residual value in the costs.

In accounting, transactions to determine the positive goodwill in acquiring an enterprise are recommended to reflect in the system of accounts, as shown in Table 1.

In international accounting practices, there are different approaches to the recognition of negative goodwill for accounting purposes (Table 2).

In the current Ukrainian practice, when an enterprise with a price below the book value of assets is bought, its amount is recognized as revenue according to the following scheme:

a) if the activity of the acquired enterprise is projected with computational losses in the future, the value of negative goodwill is recognized as an income evenly during the period of formation of such losses;

b) if the activity of the acquired enterprise is projected in the future without losses, the value of negative goodwill is recognized in income: in an amount not exceeding the fair value of the acquired non-monetary assets; evenly during the remaining period of depreciation of acquired non-current assets; in the amount exceeding the fair value of the acquired non-monetary assets in the acquisition period.

Not agreeing with the inexpediency of using negative goodwill, we suggest returning to reflection of negative goodwill (badwill). There are important grounds for application of negative goodwill in the national accounting system. Because of the crisis situations in the national economy (military actions, inflationary processes, a sharp increase in the cost of energy resources, raider seizures, etc.) that lead to bankruptcy, liquidation, change of owners, significant cheaper and depreciation of the selling value of enterprises, there are situations when the fair value of the acquired identifiable assets and liabilities exceeds the cost of acquisition of the business object.
Table 1

The recommended procedure for accounting business transactions for acquisition (combination) of an enterprise at a price exceeding the book value of its assets and liabilities

\begin{tabular}{|c|c|c|c|c|}
\hline \multirow{2}{*}{ № } & \multirow{2}{*}{$\begin{array}{l}\text { Contents of the business } \\
\text { transaction }\end{array}$} & \multicolumn{2}{|c|}{ Correspondence of accounts } & \multirow{2}{*}{$\begin{array}{l}\text { Amount, } \\
\text { thousand } \\
\text { UAH }\end{array}$} \\
\hline & & Debit & Credit & \\
\hline 1 & $\begin{array}{l}\text { The cost of acquired non-current } \\
\text { assets of the acquired enterprise }\end{array}$ & 15 «Capital investments» & $\begin{array}{l}685 \text { «Settlements with other } \\
\text { creditors» }\end{array}$ & 370 \\
\hline 2 & $\begin{array}{l}\text { The non-current assets of the ac- } \\
\text { quired enterprise are entered }\end{array}$ & $\begin{array}{l}10 \text { «Fixed Assets», } \\
12 \text { «Intangible Assets» } \\
\end{array}$ & 15 «Capital investments» & 370 \\
\hline 3 & $\begin{array}{l}\text { Materials, stocks, finished pro- } \\
\text { ducts, goods of the acquired en- } \\
\text { terprise are entered }\end{array}$ & $\begin{array}{l}20 \text { «Production reserves», } \\
22 \text { "Low value assets (LVA)», } \\
26 \text { "Finished products», } \\
28 \text { "Products» } \\
\end{array}$ & $\begin{array}{l}685 \text { «Settlements with other } \\
\text { creditors» }\end{array}$ & 130 \\
\hline 4 & $\begin{array}{l}\text { The transfer of debt rights to the } \\
\text { receivables of the acquired enter- } \\
\text { prise is reflected }\end{array}$ & $\begin{array}{l}18 \text { «Long-term accounts receivable } \\
\text { and other non-current assets», } \\
36 \text { «Settlements with suppliers and } \\
\text { contractors», } 37 \text { "Settlements with } \\
\text { different debtors» }\end{array}$ & $\begin{array}{l}685 \text { «Settlements with other } \\
\text { creditors» }\end{array}$ & 250 \\
\hline 5 & $\begin{array}{l}\text { The transfer of debt obligations } \\
\text { on the accounts payable of the } \\
\text { acquired enterprise is reflected }\end{array}$ & $\begin{array}{l}685 \text { «Settlements with other сге- } \\
\text { ditors» }\end{array}$ & $\begin{array}{l}50 \text { «Long-term loans», } \\
60 \text { «Short-term loans», } \\
63 \text { "Settlements with sup- } \\
\text { pliers and contractors», etc. }\end{array}$ & 320 \\
\hline 6 & $\begin{array}{l}\text { The payment for acquired enter- } \\
\text { prise is made }\end{array}$ & $\begin{array}{l}685 \text { «Settlements with other сге- } \\
\text { ditors» }\end{array}$ & $\begin{array}{l}11 \text { «Current accounts in na- } \\
\text { tional currency» }\end{array}$ & 1200 \\
\hline 7 & $\begin{array}{l}\text { Individual acquired non-current } \\
\text { assets is valued to market value }\end{array}$ & \begin{tabular}{|l|}
10 «Fixed Assets», \\
12 «Intangible Assets» \\
\end{tabular} & $\begin{array}{l}685 \text { «Settlements with other } \\
\text { creditors» }\end{array}$ & 110 \\
\hline 8 & $\begin{array}{l}\text { Separately acquired non-current } \\
\text { assets to market value are dis- } \\
\text { counted }\end{array}$ & $\begin{array}{l}685 \text { «Settlements with other сге- } \\
\text { ditors» }\end{array}$ & $\begin{array}{l}10 \text { «Fixed Assets», } \\
12 \text { «Intangible Assets» }\end{array}$ & 40 \\
\hline 9 & $\begin{array}{l}\text { Individual stocks are valued to } \\
\text { market value }\end{array}$ & $\begin{array}{l}20 \text { «Production reserves», } \\
22 \text { «LVA», } \\
26 \text { «Finished products», } \\
28 \text { «Products» }\end{array}$ & $\begin{array}{l}685 \text { «Settlements with other } \\
\text { creditors» }\end{array}$ & 70 \\
\hline 10 & $\begin{array}{l}\text { Discounted individual acquired re- } \\
\text { serves to market value аге dis- } \\
\text { counted }\end{array}$ & $\begin{array}{l}685 \text { «Settlements with other сге- } \\
\text { ditors» }\end{array}$ & $\begin{array}{l}20 \text { «Production reserves», } \\
22 \text { «LVA», } \\
26 \text { "Finished products», } \\
28 \text { «Products» }\end{array}$ & 30 \\
\hline 11 & $\begin{array}{l}\text { The positive goodwill is identified } \\
\text { and entered }\end{array}$ & 191 «Goodwill on acquisition» & $\begin{array}{l}685 \text { «Settlements with other } \\
\text { creditors» }\end{array}$ & $660^{*}$ \\
\hline 12 & $\begin{array}{l}\text { The amount of the monthly amorti- } \\
\text { zation of goodwill is accrued for } 20 \\
\text { years (660 thousand UAH: } 20: 12 \text { ) }\end{array}$ & 92 «Administrative Expenses» & $\begin{array}{l}133 \text { «Depreciation of intan- } \\
\text { gible assets» }\end{array}$ & 2.75 \\
\hline
\end{tabular}

Note: compiled by the author;

$G=$ CAM - INAFV $=1200000-(370000+130000+250000-320000+110000+70000-$

$-40000-30000)=660000 \mathrm{UAH}$

Table 2

Negative goodwill in key global accounting standards and reporting

\begin{tabular}{|l|l|l|}
\hline Country & \multicolumn{1}{|c|}{ Reason for applying } & \multicolumn{1}{c|}{ Content of negative goodwill } \\
\hline Ukraine & $\begin{array}{l}\text { (R(S)A) 19, «Business } \\
\text { Combinations» }\end{array}$ & $\begin{array}{l}\text { Excess of the cost of the buyer's share } \\
\text { in the fair value of the acquired identifi- } \\
\text { able assets and liabilities over the cost } \\
\text { of acquisition at the acquisition date }\end{array}$ \\
\hline IFR5 & $\begin{array}{l}\text { IFR5 3 } \\
\text { «Business Combinations» }\end{array}$ & $\begin{array}{l}\text { The recognition of negative goodwill } \\
\text { is not provided for }\end{array}$ \\
\hline USA & APB Opinion 16, Par. 67 & $\begin{array}{l}\text { Negative goodwill arises rarely due } \\
\text { to the fact that in the beginning it } \\
\text { proportionally reduces the value of } \\
\text { non-current assets, and only its ba- } \\
\text { lance is reflected as negative good- } \\
\text { will (recorded as deferred income) }\end{array}$ \\
\hline $\begin{array}{l}\text { United } \\
\text { Kingdom }\end{array}$ & $\begin{array}{l}\text { A5C «Accounting for } \\
\text { Goodwill», ED 47, Par. 30 }\end{array}$ & $\begin{array}{l}\text { «Unfavorable location» of the en- } \\
\text { terprise }\end{array}$ \\
\hline Russia & $\begin{array}{l}\text { (R(5)A) 14/2000 «Accoun- } \\
\text { ting of intangible assets» }\end{array}$ & $\begin{array}{l}\text { Discount from the price that relates } \\
\text { to deferred income }\end{array}$ \\
\hline
\end{tabular}

Note: compiled on the basis of [14-16]. 
When acquiring or combining enterprises, it is recommended that in the account 192 «Negative goodwill», the discount of the value of negative goodwill is recorded from the moment of its occurrence:

1) if the activity of the acquired enterprise is projected with a quantifiable loss in the future;

2) during the useful use (depreciation) of acquired non-current assets;

3 ) in case of excess of the fair value of the acquired non-monetary assets (assets other than cash, cash equivalents and receivables in a fixed amount of money) over the cost of negative goodwill.

Under the credit of account 192 «Negative goodwill», it is proposed to reflect the cost of occurrence of negative goodwill. In the debit, the amount of negative goodwill is recognized as income.

Also, in case of acquisition of a controlling block of shares at a price below par, the difference is reflected in the consolidated balance sheet as negative goodwill upon consolidation: Debit 685 «Settlements with other creditors» Credit 192 «Negative goodwill».

International Financial Reporting Standards (IFRS) do not compensate for impairment of goodwill due to the fact that any further increase in the cost of reimbursement will involve an increase in goodwill created within the company. This does not meet the criteria for recognition in the financial statements under IFRS and $\mathrm{R}(\mathrm{S}) \mathrm{A}$.

\section{SWOT analysis of research results}

Strengths. The strength of research is an analysis of approaches to the accounting interpretation of goodwill concept with the rationale for the need to incorporate information about the goodwill of an enterprise into accounting practices. There is also a revised procedure for recording business transactions for the purchase of an enterprise at a price exceeding the book value of its assets and liabilities. Goodwill reflection in the system of accounting of national enterprises will allow: to increase and accumulate their real book value, investment-innovative attractiveness for investors, to analyze the components with the definition of reserves of formation of the positive business reputation of the company.

Weaknesses. The regulatory and instructive framework for accounting for goodwill in Ukraine is fully in line with IFRS in terms of theory, but the practice of functioning of national enterprises differs significantly from developed countries in activity motivations, industries, financial transparency, social and environmental responsibility and intellectual constituents of fixed capital, which makes information on goodwill unclaimed.

Opportunities. Opportunities for further research are borrowing the experience of foreign countries to improve the order in which Ukrainian enterprises record information about goodwill in accounting and reporting.

Threats. Threats to research results are that goodwill, as an intangible object of the enterprise accounting and reporting system, is constantly changing, new classifications, approaches to its assessment and accounting appear. Therefore, this should be taken into account and monitored continuously to introduce changes in the procedure for assessing, accounting and reporting information in the enterprise's reporting. Also, the threats of further development of information reflection on goodwill by national enterprises are influenced by external factors, such as: changing the vector of economic development, socio-economic instability in the country, and the continuation of hostilities, etc.

\section{Conclusions}

1. The existing approaches to the general economic and accounting interpretation of goodwill and its components are analyzed. Based on the analysis, it is recommended to consider goodwill for accounting purposes, as a sum of intangible intellectual assets and synergetic effects, materialized when a company is combined or acquired in the form of the difference between its market price and the book value of assets.

2. The prerequisites and prospects for introducing information on the goodwill of the enterprise into the accounting practice are grounded.

3. A modified classification of goodwill for accounting purposes based on membership, qualitative assessment and receipt of business objects is proposed. The information needs of the main contact groups are analyzed with the definition of priority objectives, which affect the formation of goodwill.

4. The expediency of returning to use negative goodwill (badwill) in the national system of accounting and reporting of enterprises is substantiated.

5. The procedure for recording business transactions for the purchase of an enterprise at a price exceeding the book value of its assets and liabilities in the direction of increasing transparency and reliability of accounting information is specified.

Considered accounting and analytical problems and suggested recommendations for their solution provide a basis for continuing research in the direction of improving the methodology, methodology and organization of accounting, analysis and control of goodwill of the enterprises.

\section{References}

1. Country RepTrak [Electronic resource] // Reputation Institute. Available at: \www/URL: https://www.reputationinstitute.com/ research/Country-RepTrak

2. Range Resources Corporation [Electronic resource]. - Available at: \www/URL: https://finance.yahoo.com/quote/RRC?ltr=1

3. Ali, R. The moderating influences on the relationship of corporate reputation with its antecedents and consequences: A meta-analytic review [Text] / R. Ali, R. Lynch, T. C. Melewar, Z. Jin // Journal of Business Research. - 2015. - Vol. 68, № 5. - P. 1105-1117. doi:10.1016/j.jbusres.2014.10.013

4. Whiting, R. H. A tool for measuring SMEs' reputation, engagement and goodwill [Text] / R. H. Whiting, P. Hansen, A. Sen // Journal of Intellectual Capital. - 2017. - Vol. 18, № 1. - P. 170-188. doi:10.1108/jic-02-2016-0028

5. Sun, L. Goodwill impairment loss and bond credit rating [Text] / L. Sun, J. H. Zhang // International Journal of Accounting \& Information Management. - 2017. - Vol. 25, № 1. P. 2-20. doi:10.1108/ijaim-02-2016-0014

6. Kim, S. Goodwill accounting and asymmetric timeliness of earnings [Text] / S. Kim, C. Lee, S. Wook Yoon // Review of Accounting and Finance. - 2013. - Vol. 12, № 2. P. 112-129. doi:10.1108/14757701311327687

7. Grimaldi, M. Perceived benefits and costs of intellectual capital in small family firms [Text] / M. Grimaldi, L. Cricelli, M. Greco // Journal of Intellectual Capital. - 2016. - Vol. 17, № 2. - P. 351-372. doi:10.1108/jic-06-2015-0055

8. Korchemliuk, A. I. Hudvil korporatyvnykh pidpryiemstv [Text]: Monograph / A. I. Korchemliuk, I. L. Lytvynchuk, H. V. Tsyhanenko; ed. by Ye. I. Khodakivskyi. - Zhytomyr, 2013. - 160 p. 
9. Ho Kim, S. Intellectual capital vs the book-value of assets [Text] / S. Ho Kim, D. Taylor // Journal of Intellectual Capital. 2014. - Vol. 15, № 1. - P. 65-82. doi:10.1108/jic-04-2013-0048

10. Bepari, M. K. Regime change in the accounting for goodwill [Text] / M. K. Bepari, A. T. Mollik // International Journal of Accounting \& Information Management. - 2017. Vol. 25, № 1. - P. 43-69. doi:10.1108/ijaim-02-2016-0018

11. Khortiuk, O. V. Spivvidnoshennia poniat «dilova reputatsiia» «hudvil», «imidzh», «prestyzh», «renome» [Text] / O. V. Khortiuk // Chasopys Kyivskoho universytetu prava. - 2010. № 4. - P. 211-214.

12. Lehenchuk, S. F. Bukhhalterske vidobrazhennia intelektualnoho kapitalu [Text]: Thesis of PhD: 08.06.04 / S. F. Lehenchuk. Kyiv, 2006. - $21 \mathrm{p}$

13. Levchenko, O. P. Problemy obliku intelektualnoho kapitalu [Text] / O. P. Levchenko // Investytsii: praktyka ta dosvid. 2009. - № 22. - P. 37-39.

14. International Accounting Standard [Electronic resource]. Available at: \www/URL: http://eifrs.ifrs.org/eifrs/

15. Statement of Financial Accounting Standards No. 142. Goodwill and Other Intangible Assets [Electronic resource]. - Financial Accounting Standards Board of the Financial Accounting Foundation, June 2001. - Available at: \www/URL: http:// www.fasb.org/resources/ccurl/731/820/fas142.pdf

16. Pro zatverdzhennia Polozhennia (standartu) bukhhalterskoho obliku 19 [Electronic resource]: Decree of the Ministry of Finance of Ukraine from 07.07.1999 № 163. - Available at: \www/URL: http://zakon3.rada.gov.ua/laws/show/z0499-99
17. Tax Code of Ukraine [Electronic resource]: Law of Ukraine from 02.12.2010 № 2755-VI. - Available at: \www/URL: http://zakon3.rada.gov.ua/laws/show/2755-17

\section{ОБОСНОВАНИЕ ПОРЯДКА ОТРАЖЕКИЯ ГУДВИЛЛА В СИСТЕМЕ УЧЕТА НАЦИОНАЛЬНЫХ ЛРЕДПРИЯТИЙ}

Проведен анализ существующих подходов к общеэкономическому и регламентированному бухгалтерским учетом трактовок понятия гудвилла. Рассмотрены предпосылки внедрения в учетную практику и постепенного расширения использования в национальной системе учета гудвилла предприятия. Предложена модифицированная классификация гудвилла по признакам принадлежности, качественной оценки и поступления бизнесобъектов. Уточнен порядок учета положительного гудвилла и доказана целесообразность возврата к использованию в национальной системе учета отрицательного гудвилла (бедвилла)

ключевъе слова: гудвилл, бухгалтерский учет, классификация гудвилла, объединение предприятий, отрицательный гудвилл (бедвилл).

Izmaylov Yaroslav, PhD, Associate Professor, Department of International Economics, Kryvyi Rih Economic Institute, SHEI »Kyiv National Economic University named after Vadym Hetman», Ukraine, e-mail: izmyar@ukr.net, ORCID: http://orcid.org/0000-0003-4853-205X

Zhurylo V.

\section{STUDYING THE EUROPEAN CONSUMER BEHAVIOR AND MOTIVATIONS TOWARDS TOURISM SERVICE IN THE CONDITION OF GLOBALIZATION}

Розглянуто особливості сучасного етапу розвитку європейського туристичного ринку та проаналізовано внутрішні та зовнішні чинники, які впливають на формування ринкової поведінки споживачів. За результатами маркетингового дослідження туристичного ринку Великої Британії визначено ключові мотивачії споживачів, напрями трансформачій споживчої поведінки під впливом глобалізації, охарактеризовано профілі цільових сегментів.

Ключові слова: туристичний ринок, глобалізачія, ринкова поведінка споживачів, споживчі мотивації.

\section{Introduction}

Due to the enhancing processes of integration and globalization, travel services industry is becoming one of the world economy sectors, which has an important place in modern international economic relations, has the most intensive development and leads to erasing of economic and cultural borders between the countries. The development of transport infrastructure, reducing the cost and spreading air transport services, spreading information technology and communications, making one common information field which is available for the unlimited number of users, increasing material wealth, development of social programs in most developed countries - this is an uncompleted list of factors which cause the popularization of international tourism and induce to the formation of the world tourism market.
The tourism industry is one of the key sectors of the national economy in many European countries. Thus, the European tourism industry, excluding related tourism sectors of the economy (trade, transport, catering etc.) creates more than $4 \%$ of GDP in Europe. The tourism industry and related sectors of the national economy provide employment for $12 \%$ of the working population of the enlarged EU that creates 24 million workplaces [1]. In addition to economic benefits, tourism has a significant social impact on the lives of European society. The active popularization of tourism as a social phenomenon is that it is based on satisfying constant people needs in learning the environment and in learning themselves as part of the world. The globalization of world tourism market creates intercultural dialogue between European countries and forms the basis for the formation of European identity as a single cultural and historical center. 